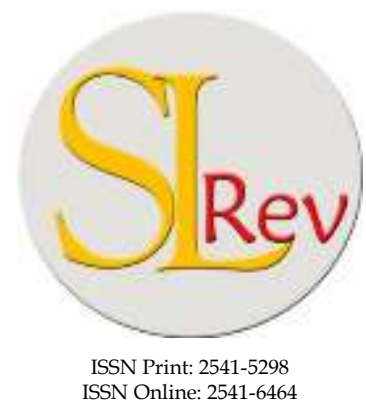

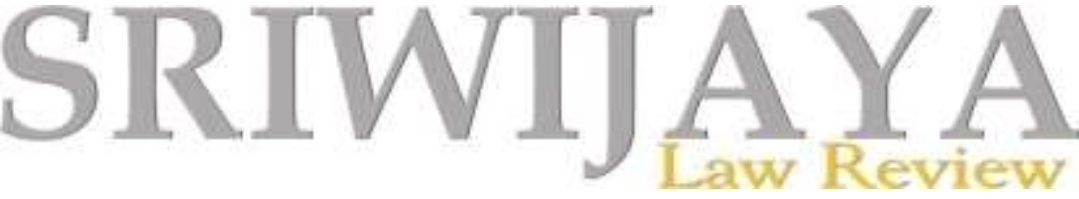

Editorial Office: Faculty of Law, Sriwijaya University, Jalan Srijaya Negara, Palembang, South Sumatra 30139, Indonesia. Phone: +62711-580063Fax: +62711-581179

E-mail: sriwijayalawreview@unsri.ac.id|sriwijayalawreview@gmail.com

Website:http://journal.fh.unsri.ac.id/index.php/sriwijayalawreview

\title{
Legal Protection of Patient Rights in Indonesia
}

\author{
Istiana Heriani ${ }^{*}$, Gunarto**, and Anis Masdhurohatun**
}

\begin{abstract}
This study examines the legal protection of patient rights in health services in Indonesia. The aims of the study are to find out how the legal protection of patients as consumers in receiving health services and what factors affecting the legal protection of patients' rights in receiving health services. The method employed in this study is a normative study by analysing data obtained from library. The data gathered are in form of secondary data. All the data collected are analysed descriptive qualitative. The problem raised herein is Law Number 44/2009 Concerning the Hospital is not fully well implemented. The results showed that there were many factors influent the effectiveness of Law Number 44/2009 above. The conclusion drawn up that the malpractice in terms of providing medical care may cause disharmony between physicians and patients; the facilities and infrastructures in the health care provided for in the hospital do not support the patients' rights to obtain health care. Any responsibility borne to the hospital may only in the case of the patients suffered from the malpractice. Should this happen the patients can submit any formal complain to the Court.
\end{abstract}

Keywords: Consumers; Health Complain; Health Services; Legal Protection; Patients.

ARTICLE HISTORY:

\section{DOI: 10.28946/slrev.Vol3.Iss1.134.pp75-85}

Received: Jun 05, 2018;

Reviewed: Dec 04, 2018;

Accepted: Jan 12, 2019;

Published: Jan 31, 2019.

* Faculty of Law, University of Islam Kalimantan, E-mail: iheriani2579@gmail.com

** Faculty of Law, University of Islam Sultan Agung, Semarang

\section{INTRODUCTION}

In Indonesian laws play an important role in various terms of the life of society and the state. One of them is in the field of health. It is human rights and one element of wellbeing to be realized in accordance with the ideals of Indonesia referred to Pancasila and the 1945 Constitution of the Republic of Indonesia.
Legal protection is a right for every citizen, in which every citizen is entitled to the protection of the law without any discrimination. As for the matter specified in article 28D the 1945 Constitution of the Republic of Indonesia which States that the State is obliged to give confessional guarantees, protection and legal certainty and justice that leads to legal protection of the country that includes health protection, social protection, protection, protection of the cultural, political and other protection.

To obtain optimal health for everyone, which is part of welfare, one needs the support of the law to implement it. The first effort was conducted disease treatment and health recovery, and gradually developed the health of a comprehensive, integrated and sustainable manner including the promote 
(increase), preventive (healing) and rehabilitative (recovery).

Efforts of the implementation of the health are affected by environmental factors of social culture, including economic, physical environment, biological nature, dynamic, and complex ones. The government through the health system tried to organize health that is comprehensive, integrated, equitable, acceptable, and affordable by all levels of society in order to achieve the optimal degree of health. ${ }^{1}$

To realize the optimal health for everyone, it must constantly be conducted in earnest for the implementation of a national development perspective, the guarantee for the maintains of health, professionalism enhancement, and health decentralization. These activities are sufficient. The legal health is intended for the rule of law and comprehensive protection for health services in relation to health services in society. There are essentially two kinds of individual basic rights, namely the right to information (getting information) and the right to selfdetermination (getting to self-determine).

Initially, the decision of a physician is a man in the form of seeing physicalism with the developments in the field of social and culture accompanying the development of the society that has brought changes to the status of human beings as objects. Medical science to be subject to the public is very important. Consequently, we need caution and professionalism in health care providers to support the government's program to make Indonesia healthy. It is then essential to have health professionals to be more

1 Bahdar Johan Nasution, Hukum Kesehatan dan Pertanggungjawaban Dokter, Jakarta: Rhenika Cipta, 2005, p79. professional and responsible in the field of health services.

As for the national development program of seeking to increase the degree of health through the development and stabilization of all health system policies, it is a logical consequence of the overall quality of integrated medical care and therefore the quality of the service and provision of facilities of each hospital should be provided to all parties with relief. At the moment, the health management which is the key to the success of the development of health is not yet entirely sufficient. Some of the contributing factors are the inadequate system of public health information, the integration of health services not running well, and incomplete control, surveillance, and assessment of the program objectives. Recently, the media often highlights the healthcare in particular, regarding the relationship between patients and physicians, insufficient provision of facilities, the occurrence of malpractice cases. Most focus on the lack of the number of physicians in catering for the rights of patients, procedures (patient), different medical services between the rich and poor, and physicians being on time and prompt for emergency patients.

Based on the fault or negligence of a physician in the medical profession, it is important to take into account that its impact is very harmful. In addition to the damage or decline of public confidence in the medical profession, it results in losses to the patient. ${ }^{2}$ A medical action carried out by a doctor can be classified as a medical action that is malpractice if the medical action fulfils the form of default (poor performance), and / or

Article 50 of the Law No. 29 of the year 2004 the Practice of Medicine. 
fulfils the elements of illegal acts and the medical action causes harm to the patient or victim malpractice both physically and mentally can be carried out demands in the form of compensation or imprisonment. This also shows the public awareness to know the rights of patients they have as consumers of health services. ${ }^{3}$

Furthermore, if the rights are violated, the legal remedies available to patients are:

1. Submitting a lawsuit to a business actor, both to the general justice institution and to an institution specifically authorized to resolve disputes between consumers and business actors ${ }^{4}$

2. Report to the police or other investigators. This is because, in every law mentioned above, there are provisions for criminal sanctions for violating the rights of patients. ${ }^{5}$

\section{RESEARCH METHOD}

This paper used a normative method $^{6}$ focusing on the legal protection of the rights of patients as a consumer of justice-basedhealth service. It is legal research in the realm of normative or doctrinal study

This paper used three approaches that have significant relevance, i.e., the legislation, conceptual, and philosophical approaches. Legislation approach (statute approach) used as the subject set off from legislation, i.e. the problem of the legal

3 Sabungan Sibarani, 2017, Aspek Perlindungan Hukum Pasien Korban Malpraktik Dilihat Dari Sudut Pandang Hukum di Indonesia, Jakarta: Jurnal Atma Jaya, p10.

4 Article 45 of The Law Number 8 of 1999 concerning Consumer Protection.

5 https://www.hukumonline.com/klinik/detail/cl24 31/hak-pasien-atas-pelayanan-kesehatan-dirumah-sakit/ (retrieved: January 16, 2019).

6 Soetandyo Wignjosoebroto, Pergeseran Paradigma Dalam Kajian-Kajian Sosial dan Hukum, Malang: Setara Press,2013,p21. protection of the patients' rights as justicebased-health-service consumers. The conceptual approach was set off from the views and doctrines developed in the jurisprudence to find ideas leading to the concepts of law, a legal sense and the principles of law relevant to the issues faced. Using this conceptual approach, the researcher first invents the concept of supervision set out in Consumer Protection Law and Health-y Law, assessed and understood it, and com-pared with the supervision concept derived from the theory and ideas of experts. This way, it is eventually able to find the meaning of supervision of legal protection referred to in Consumer Protection Law and Healthy Law.

The philosophical approach was used in order to be able to interpret the concept of legal protection against the rights of the patients in receiving the medical services and the rights of the patients as a consumer health justice.

Sources and types of data consist of primary data and secondary data, i.e. as follows: ${ }^{7}$

\section{Primary Data}

Primary data is the main data obtained directly from the field of research with How to conduct an interview with the speaker to get the data you need in the research.

\section{Secondary Data}

Data is crucial in a study because in normative legal research studied is the material law that contains rules that normative in nature.

In this study, the method of analysis used is the qualitative method. ${ }^{8}$ The

Abdulkadir Muhammad, Hukum dan Penelitian Hukum, Bandung: Citra Aditya Bakti, 2014, p61. 
application of this methodology are flexible, not very detailed, does not have to define the concept, giving the possibility for changes while found more basic facts, interesting, unique and meaningful in the field. ${ }^{9}$

\section{RESULT AND DISCUSSION Protection of law of the Rights of Patients in Having Medical services}

Making an effort to improve the quality of public and medical services can be carried out either through accreditation, certification, or the process of improving the quality. In other words, it means that the overall efforts and activities are comprehensive and integrative regarding the structures, processes, objectives, systems, and sustainable monitoring and assessment of the service quality for patients. The opportunity of improving the patient care and problem-solving disclosed so that the

8 Qualitative research we mean any kind of research that procedure findings not arrived at by means of statistic procedures or other means of quantifications. It can refer to research about persons' lives, stories, behaviours, but also about organizations. Functioning, social covenants or intellectual relationship", Anselmus Strauss and Juliat Corbin, Basic of Qualitative Research, Grounded Theory Procedure and Technique, Sage Publication, Newbury, Park London, New Delhi, 1979, p17. John W Creswell, Research Design: Qualitative \& Quantitative Approaches, Sage Publication, Thousand Oaks, London, New Delhi, 1994; Robert Bog and Steven J. Taylor, Introduction to Qualitative Research Methods: A Phenomenological Approach To The Social Science, A Willey-Interscience Publication, New York London Sydney Toronto, 1975; Michael Quinn Patton, Qualitative Evaluation And Research Methods, Second Edition, Sage Publication, Newbury Park London New Delhi, 1980.

9 Burhan Bungin (ed), 2003, Analisis Data Penelitian Kualitatif, Jakarta: Raja Grafindo Persada, p39. service provided by the health personnel of the hospital can be useful.

The quality of health care provided by the hospital health personnel needs to be supported by available resources including human resources, facilities, infrastructures, medical equipment, and the hospital. Generally, public hospitals had medical treatment services similar to those of private hospitals; therefore, most people make more use of public hospitals to acquire health care. Consequently, it is vital to support public health. However, at a cost of a relatively cheap, it might alleviate the health service level to patients. Poor patients were only able to have low-cost medical treatment, and unfortunately, such hospitals existed just in certain areas. There was no other choice for patients to choose the best medical treatment, especially on emergency health conditions. Also, in a rural area, there is only one medical specialist. It is entirely difficult to provide maximum service to patients, and this was in contrast with the code of ethics of medicine.

A hospital mostly determined by the success of those who work in the hospital such as physicians, nurses, and other personnel. There are still some of the people in Indonesia complaining of health services due to limited skills of the physicians or a lack of caution or negligence in performing their profession affecting the safety of patients. Other patient rights as consumers are the right to be heard and get compensation if the services obtained are not as they should. The community as consumers can submit their complaints to the doctor or the hospital as an effort to repair the hospital in its service. ${ }^{10}$

10 Ni Luh Gede, Yogi Arthani, Made Emyand Andyani Citra, 2008, "Perlindungan Hukum Bagi 
Regarding the standard of hospital service, there are three things that must be fulfilled in hospital service, which is: Standard Operating Procedures; Standard of Medical Service, and Standard of Nursing Care. According to the explanation of Article 13 of Law Number 44/2009, Standard Operating Procedure is instruction equipment/steps that is standardized to finish the process of routine work. Standard of Medical Service is guidance for medical workers to give service and do action in gynaecology and obstetrics. Standard of Nursing Care is a statement of quality that expected in order to get health service. ${ }^{11}$

Health services are important to be maintained and improved in their quality of the service standards for a society as a patient can feel the service provided. In general, in the process of treatment administered by a physician, patients always had treatment without knowing the actions treated to them. In fact, the information about medical treatment patients get is very important to be informed to avoid problems or disappointment to them later. But most people simply trust the medical treatment they get from the physicians because they consider all the medical treatments are conducted for the sake of their health. This occurs due to the lack of patients' knowledge. They don't need to know the truth about the treatment given by the physician because everything is entrusted to the physician in charge. The lack of services

Pasien Selaku Konsumen Jasa Pelayanan Kesehatan Yang Mengalami Malpraktik," Jurnal Advokasi Fakultas Hukum Universitas Mahasaraswati, p121.

11 Zahir Rusyad, Suhariningsih, Bambang Winarno, and Abdul Rachmad Budiono, 2018, "Legal Protection of Patient Rights in Fulfilling Health Service by Doctor in Hospital," Journal of Law, Policy and Globalization, www.iiste.org, p119. provided by health professionals to the public as consumers resulted from the following:

\section{The physician and patient.}

The basis of the legal relationship between the patient and the patient's doctor Hospital is based on the book of the law of civil law book III of the Alliance (Van Verbintennisen) ${ }^{12}$ Doctors, patients, and the hospital is referred to as a subject of law, in which doctors and patients is the subject of legal persons da Hospital is the subject of the law not the people (legal entities).

Transaction therapeutic the relationship of doctors and patients began when a patient comes to a doctor to seek help over the problem in the field of health so that the existence of such things already there is a contract or agreement between doctor and patient the so-called the Alliance contract/transaction/therapeutic.

A medical service exists in law between a physician or hospital as a provider of health care and patients as recipients of health care services. The relationship occurring between patients and hospitals can be distinguished in two kinds of agreement, firstly, in the health care, there is an agreement between the hospital and its patients that the hospital provides treatment rooms and has the authority to conduct the treatment. Secondly, in the medical services where there is an agreement between the hospital and its patients, the medical personnel of the hospital will attempt to its full potential to cure the patients through medical treatment. ${ }^{13}$

12 Tutik, Titik Triwulan, Hukum Perdata dalam Sistem Hukum Nasional, Jakarta: Intermasa, 2008, p30.

13 Fried Ameln, Kapita Selecta Hukum Kedokteran,Jakarta: Grafikatama, 1999, p77. 
The patient actually is the factor liveware. The patient should be seen as the subject of the have great influence over the end result is not a service mere object. The rights the patient must be met given the patient's satisfaction be one barometer the quality of service while patient dissatisfaction can be the base demands law. ${ }^{14}$

In this connection the position of doctor with patient does not equal ${ }^{15}$ i.e. position higher than doctors' patients because doctors deemed to know about everything related to illness and healing. While the patient does not know anything about it until the patient is handed over his fate is entirely in the hands of a doctor. Legal relationship arises when patients call the doctor because he feels there is something that feels dangerous to his health. Psychological circumstances giving warning that he felt ill, and in this case, a doctor who she thought had been able to help him and provide relief aid. So, the doctor's position is considered higher by patients, and its role is more important than the patient.

Based on these provisions, then the relationship law between patients and physicians is that a physician and a patient each has to comply with the conditions in the rule of law or terms of the legitimacy of an agreement listed in Article 1320 of Civil Code. The implementation of the agreement should be implemented in good faith in accordance with the provisions of Articles 1338 and 1339 of Civil Code. With these provisions, patients are already protected by law because, in addition to physicians,

14 Jusuf Hanafiah dan Amri Amir, Etika Kedokteran dan Hukum Kesehatan, Jakarta: EGC, 1989, p21.

15 Talcott Parsons, 1969, "Research with Human Subject and The Profesional Complex," Jurnal Daedalus, p336. patients also need legal protection proportionately by Civil Code in general and by Consumer Protection Law in particular. Protection is mainly directed to the possibilities that physicians and other health personnel conduct errors of negligence. In other words, patients have legal protection of having proper and optimal health services.

\section{The system of legal protection for patients that are determined by the hospital.}

A hospital has to ensure legal protection for physicians/health personnel in order not to cause a medic to deal with patients. Patients gain legal protection as the consequence of the responsibility of the hospital, physicians, or health personnel. To create protection for patients then the parties must understand the rights and obligations attached to it, including the health services which become the responsibility of the profession given to the health services. Therefore, physicians and health personnel need to understand the legal basis of treatment between them and patients, know and understand the rights and obligations of patients as well as the rights and obligations of the physicians, and it is obligatory for them to keep the office, work, and medical treatment results secret to avoid any possibility of something bad happening to patients in health services. If there are complaints from the patients about the service provided, they will be processed in accordance with the rule of law. The consumer protection also protects patients related to their rights and obligations as consumers both by physicians and nurses. In fact, the protection of patients is clearly stipulated in Act No. 36 of 2009 on Health, Article 56 of the provisions of, among others, as follows: "(1) everyone has the 
right to accept or reject part or all of the aid that will be given to him/her after receiving and understand information about the treatment is complete. (2) The right to accept or reject as referred to in paragraph (1) does not apply to: (a) patients with diseases of which the disease can quickly spread into a society; (b) of someone who is unconscious; or (c) a mental disorder. (3) the Uniform Code of the right to accept or reject as referred to in paragraph (1) is set in accordance with the provisions of the legislation".

\section{The facilities and infrastructure are inadequate.}

The success of a medical service is highly dependent on the quality of human resources supported by the available facilities. Facilities and infrastructures of the hospital of a local government which is located in a remote area will certainly not be comparable to the one found in a city. For example, a hospital in a remote area has only one ambulance that makes its service very limited. The hospital located far from residential areas is time-consuming for those who need quick medical treatment and get hospitalized in a patient ward.

\section{The quality of health services given by the physicians or health personnel, and the hospital.}

The role and functions of the hospital as a place of providing medical service professsionals will be closely related to three elements: first, the element of guaranteed quality, second, the part of profit or benefit reflected in the service quality and third, the laws regulating the hospital in general and medical service. ${ }^{16}$ The elements are beneficial for patients and physicians or health professionals due to a relationship that complements each other. Health services are adequate in desperate need of infrastructures that support them. In addition, a physician should have good knowledge of standard medical services and professional medical, understanding of medical malpractice, handling of the emergency room, medical records, euthanasia, and others. All need to be explored professionally in order to prevent medical acts causing errors and or negligence of physician or health personnel and the hospital that will cause harm to patients.

\section{The rights of patients as consumers.}

The right of patients as service health consumers set out in the Consumer Protection Law of the consumer rights provided in Article 4 of the letters c, d, e and $\mathrm{f}$ The Law Number 8 of 1999 concerning Consumer Protection, i.e., a. rights for the information, clear and honest about the condition, and guaranteed goods and/or services; b. rights to hear the opinions and complaints to the House and services that are used; c. rights to get advocacy, protection, and settlement of disputes of consumer protection; d. rights to get development and consumer education. ${ }^{17}$

Many communities lack an understanding of what their rights and obligations when becoming a patient at the hospital. In fact, there are four overarching goals related Community law rights and obligations as a patient. The fourth ACT it is The Law Number 36 of 2009 concerning Health, ACT

16 Titik Triwulan Tutik dan Shita Febriana, Perlindungan Hukum Bagi Pasien, Jakarta: Prestasi Pustaka Publisher, 2010, p1.

17 Sidabalok Janus, 2014, Perlindungan Konsumen di Indonesia, Bandung: Citra Aditya Bakti, p101. 
The Law Number 29 of 2004 concerning Practice Medicine, Act The Law Number 44 of 2009 concerning hospital, The Law Number 8 of 1999 concerning Consumer Protection.

The rights of these patients, said Luhut, including rights to get a rather simplistic explanation regarding medical action, the right to ask for the opinion of a doctor or another doctor, the right to obtain services, the right of refusing therapeutic action, and the rights to obtain the rules and code of conduct of the hospital. In addition, the right to obtain services that are humane, fair, honest and without discrimination. ${ }^{18}$

\section{Legal Protection of Patient Rights as a Based-on-Justice Health Consumer}

Accountability should have bases causing the onset of the legal rights of a person to sue people and in the form of a right that provides the duty of the law of other people to give its response. The general principles of responsibility of the law are:

1. Based on elements of a based-on fault liability;

2. The principle of presumption to be responsible (presumption of liability).

3. The principle of the doubt to be not always responsible (presumption of nonliability).

4. The principle of the responsibility to be absolutely (strict liability).

5. The principle of the responsibility with restrictions (Limitation of liability). ${ }^{19}$

Therefore, the principle bases of liability without based on fault and

\footnotetext{
18 https://www.hukumonline.com/berita/baca/lt56cd a4554dd92/yuk--pahami-hak-dan-kewajibanpasien-ketika-di-rumah-sakit (retrieved: January 21, 2019).

19 Titik Triwulan Tutik dan Sinta Febriana, Note 12, p49.
}

accountability without error (liability without fault) are known as the responsibility of the risk of (risk liability) or there are two categories of the hospital as the defendant which are state-owned hospital and a private hospital.

With regard to the public hospital, the governing board of trustees is provided for in Article 1365 Code of Civil Law. An employee working in public hospitals are civil servants and the State as a legal entity can be required to pay compensation for the actions of the civil servants carrying out their duties to the detriment of other parties. As for the management of a private hospital, it is applied because of Articles 1365 and 1367 Code of Civil Law. A private hospital as a legal entity has a wealth of itself and can act in law and can be prosecuted just like humans. Those who work at Public Hospitals and private ones have power in their professions; both the powers of a civil servant and a private employee have a difference in charge.

If a physician who is a civil servant makes errors or omissions or malpractice in action, s/he is given a sanction in the form of transferring him/her to other health agencies, or getting suspended, or even getting dishonourably discharged if it is considered violating the discipline. It is in accordance with the regulations of the discipline of civil servants as stipulated in Regulation No. 8 of 1974 on basic employment regulation which was converted into Regulation Number 43 of 1999. As for private physicians, if they make a mistake, they will get the sanctions in the form of dismissal by the Hospital where they work in accordance with the agreement of their employment contract.

Causing losses to the patient by the physician will be a burden to the hospital. A 
physician is limited to do his/her job in accordance with the provision and standards outlined for the profession. So, when patients suffer from incurability, the physician is not allowed to carry on his/her job in accordance with the procedures. However, if a physician does his job without following the procedures, the patients can sue a loss to him.

Regarding the responsibility provided by the General Hospital, if negligence is performed by physicians, patients who suffer a loss can demand compensation to the hospital. Patients who get offended due to the medical services they have can submit complaints or loss to the director of the Hospital and then to the medical committee to provide information about the complaint or disadvantage of the service conducted by the physician or other medical personnel. Then the director of the hospital would call on them, the patients and physician, to be questioned of what happened between them and find out the solutions.

If it is evident that the losses suffered by the patient were caused by the negligence of the physician, the director of the hospital will decide on who will be responsible for the losses, the hospital or the physician. If the Hospital cannot get the settlement which means the patient is not satisfied with the decisions taken by the director of the hospital or there is no solution to the problem, the patient himself/herself can report the dispute to the Department of Health or the Indonesian Physicians Association (IDI) to be resolved. If the dispute is still not resolved, the patient can complain in writing to the Chairman of the Assembly of Discipline of Medicine of Indonesia in accordance with Article 66, paragraph 1 of Law No. 29 of 2004 Practice
Medicine. Patients can file a dispute to the District Court. If physicians conduct an institutional malpractice, in terms of jurisdiction, all of them may be sued to criminal court and civil as malpractice to be proved based on standard medical profession.

If a physician is proved to have deviated from the standard of the medical profession and $\mathrm{s} / \mathrm{he}$ keeps informed consent then $\mathrm{s} / \mathrm{he}$ is not convicted or free to make restitution. The Article 1365 Code of Civil Law states that investors should compensate fully. From these provisions the hospital and health professionals should be more careful in doing medical treatment in which the patients entrust entirely to their medical actions.

According to the legislation of the Republic of Indonesia, number 8 Year 1999 about consumer protection article 4 grain (c) stated that consumer rights are the right to information, clear and honest about the condition and guarantee of the goods and/or services. The rights of other patients as a consumer is the right to be heard and get compensation if the service was not obtained as to where appropriate, the community as a consumer can convey the complaint to the hospital as House pain in his Ministry ${ }^{20}$. A mismatch can disrupt the health care process of healing patients treated and can result in lawsuits from parties who feel aggrieve. The hospital is legally responsible for all the losses inflicted upon the negligence committed health workers at the hospital.

Efforts to minimize the lawsuits against hospitals and its health workforce are primarily one of the efforts to prevent the risk of on-going patient safety-oriented. To support these efforts, it will need the

20 Susatyo Herlambang, Etika Profesi Kesehatan, Yogyakarta: Gosyen Publishing, 2011, p43. 
necessary legal device adequate health, so that the existence of legal certainty and the protection of overall good for healthcare facilities as well as for health care personnel who provide services ${ }^{21}$. The combination of the existence of the law with the law of health in various regulations in the health service in particular affect the behaviour of obedience and adherence to orders or prohibition of the Act that apply to the parties that are inter-related in the support the Ministry of health, professional and reliable.

\section{CONCLUSION}

The legal protection of health services on the patient health care as consumer of health services is set out in the consumer protection and the Law of the Republic of Indonesia No. 29 of 2004 the practice of medicine. The malpractice in terms of providing medical care less than the maximum by the health personnel is caused by first, the relationship between physicians and patients is that the physician is more dominant a physician than his/her patients because the patient always obeys all orders and directions given by physician without knowing the truth. Second, it is the systems of legal protection of the hospital. Third, the facilities and infrastructures are inadequate. Fourth, it is the quality of medical care provided by the physicians and health personnel and the hospital. Fifth, the rights of patients as consumers who suffer from malpractice in health care are not fulfilled.

Responsibility of the hospital to the losses suffered by a patient because of malpractice is that if the event of a medical

21 Machli Riyadi dan Widia Lidia, Etika dan Hukum Kebidanan, Yogyakarta: Nuha Medika, 2017, p121. malpractice resulted in the patient's disappointment with the director of the hospital or health personnel or Minister of Health due to the unexpected result, the patient can complain formally to the local criminal and civil court. According to Article 1365 Code of Civil Law, employees working in public hospitals are civil servants and the State as a legal entity can be required to pay compensation for their actions in carrying out their duties that cause the detriment of other parties. If those civil servants conduct negligence or malpractice in action, they are given a sanction in the form of transferring their jobs to other health agencies, or the suspension, or even getting dishonourably discharged if it is considered violating the discipline. In addition, patients suffering the loss can demand compensation to the hospital. Patient feeling aggrieved for medical services they have can submit complaints or loss to the director of the hospital and then to the medical committee to provide information about the complaint or disadvantages from the medical treatment service a physician or medical personnel provides.

\section{REFERENCES \\ Books}

Bungin, Burhan (ed). 2003. Analisis Data Penelitian Kualitatif. Jakarta: Raja Grafindo Persada.

Fred, Ameln. 1999. Kapita Selekta Hukum Kedokteran. Jakarta: Grafikatama Jaya.

Hanafiah, Jusuf dan Amri Amir. 1989. Etika Kedokteran dan Hukum Kesehatan. Jakarta: EGC.

Herlambang, Susatyo. 2011. Etika Profesi Kesehatan. Yogyakarta: Gosyen Publishing. 
Hermien, Koeswadji Hadiati. 2002. Hukum dan Masalah Medik. Surabaya: Airlangga Press Surabaya.

Muhammad, Abdul Kadir. 2014. Hukum dan Penelitian Hukum. Bandung: Citra Aditya Bakti.

Riyadi, Machli dan Lidia Widia. 2017. Etika dan Hukum Kebidanan. Yogyakarta: Nuha Medika.

Sidabalok, Janus. 2014. Perlindungan Konsumen di Indonesia. Bandung: Citra Aditya Bakti.

Tutik, Titik Triwulan dan Sinta Febriana. 2010. Perlindungan Hukum Bagi Pasien. Jakarta: Prestasi Pustaka Publisher.

Tutik, Titik Triwulan. 2008. Hukum Perdata dalam Sistem Hukum Nasional. Jakarta: Intermasa.

Wignjosoebroto, Soetandyo. 2013. Pergeseran Paradigma Dalam Kajian-Kajian Sosial dan Hukum. Malang: Setara Press.

\section{Journals}

Gede, Ni Luh., Yogi Arthani, Made Emy dan Andyani Citra. 2013. "Perlindungan Hukum Bagi Pasien Selaku Konsumen Jasa Pelayanan Kesehatan Yang Mengalami Malpraktik." Jurnal Advokasi. Fakultas Hukum Universitas Mahasaraswati. Denpasar.

Parsons, Talcott. 1969. "Research with Human Subject and the Professional Complex." Jurnal Daedalus. Journal of the American Academy of Art and the Sciences.

Rusyad, Zahir, Suhariningsih, Bambang, Winarno, dan Abdul Rachmad Budiono. 2018. "Legal Protection of Patient Rights in Fulfilling Health Service by Doctor in Hospital." Journal of Law, Policy and Globalization.www.iiste.org.
Sibarani, Sabungan. 2017. "Aspek Perlindungan Hukum Pasien Korban Malpraktik Dilihat Dari Sudut Pandang Hukum Di Indonesia." Jurnal Fakultas Hukum Atma Jaya. Jakarta.

Strauss, Anselmus and Juliat Corbin. 1979. Basic of Qualitative Research, Grounded Theory Procedure and Technique. "Journal Sage Publication." Newbury, Park London, New Delhi.

\section{World Wide Web}

Hukumonline. (2010) Hak Pasien atas Pelayanan Kesehatan di Rumah Sakit. [Online] Available at: https://www.hukumonline.com/klinik/detail/cl2431/hak-pasienatas-pelayanan-kesehatan-di-rumah-sakit/ [retrieved: January 16, 2019].

Hukumonline. (2016) Yuk, Pahami Hak dan Kewajiban Pasien Ketika di Rumah Sakit. [Online] Available at: https://www.hukumonline.com/berita/baca/1t56cda4554dd92/yu k--pahami-hak-dan-kewajiban-pasienketika-di-rumah-sakit [retrieved: January 21, 2019].

\section{Laws}

The 1945 Constitution of the Republic of Indonesia.

The Law Number 8 of 1999 concerning Consumer Protection.

The Law Number 29 of 2004 concerning Practice Medicine.

The Law Number 36 of 2009 concerning Health.

The Law Number 36 of 2014 concerning Medical Personnel.

The Law Number 44 of 2009 concerning Hospital. 